OPEN ACCESS

Edited by:

Tim Daniell,

James Hutton Institute,

United Kingdom

Reviewed by:

Claudia Knief,

University of Bonn, Germany

Hannu Fritze,

Natural Resources Institute Finland,

Finland

*Correspondence:

Carsten S. Jacobsen

csj@envs.au.dk

${ }^{\dagger}$ These authors have contributed equally to this work.

Specialty section:

This article was submitted to

Terrestrial Microbiology,

a section of the journal

Frontiers in Microbiology

Received: 03 April 2017 Accepted: 11 July 2017

Published: 28 July 2017

Citation:

Bang-Andreasen T, Nielsen JT,

Voriskova J, Heise J, Rønn R,

Kjøller $R$, Hansen HCB and

Jacobsen CS (2017) Wood Ash Induced pH Changes Strongly Affect

Soil Bacterial Numbers

and Community Composition.

Front. Microbiol. 8:1400.

doi: 10.3389/fmicb.2017.01400

\section{Wood Ash Induced pH Changes Strongly Affect Soil Bacterial Numbers and Community Composition}

Toke Bang-Andreasen ${ }^{1,2,3+}$, Jeppe T. Nielsen ${ }^{3,4 \dagger}$, Jana Voriskova ${ }^{3,5,6}$, Janine Heise $^{7}$, Regin Rønn ${ }^{2,8,9}$, Rasmus Kjøller ${ }^{2}$, Hans C. B. Hansen ${ }^{4}$ and Carsten S. Jacobsen 1,3,6*

' Department of Environmental Science, Aarhus University, Roskilde, Denmark, ${ }^{2}$ Department of Biology, University of Copenhagen, Copenhagen, Denmark, ${ }^{3}$ Department of Geochemistry, Geological Survey of Denmark and Greenland (GEUS), Copenhagen, Denmark, ${ }^{4}$ Department of Plant and Environmental Sciences, University of Copenhagen, Frederiksberg, Denmark, ${ }^{5}$ Ecology Department, Climate and Ecosystem Sciences, Lawrence Berkeley National Laboratory, Berkeley, CA, United States, ${ }^{6}$ Center for Permafrost (CENPERM), University of Copenhagen, Copenhagen, Denmark, ${ }^{7}$ Section for Geomicrobiology, GFZ German Research Centre for Geosciences, Potsdam, Germany, ${ }^{8}$ Key Laboratory of Urban Environment and Health, Institute of Urban Environment, Chinese Academy of Sciences, Xiamen, China, ${ }^{9}$ Arctic Station, University of Copenhagen, Qeqertarsuaq, Greenland

Recirculation of wood ash from energy production to forest soil improves the sustainability of this energy production form as recycled wood ash contains nutrients that otherwise would be lost at harvest. In addition, wood-ash is beneficial to many soils due to its inherent acid-neutralizing capabilities. However, wood ash has several ecosystem-perturbing effects like increased soil $\mathrm{pH}$ and pore water electrical conductivity both known to strongly impact soil bacterial numbers and community composition. Studies investigating soil bacterial community responses to wood ash application remain sparse and the available results are ambiguous and remain at a general taxonomic level. Here we investigate the response of bacterial communities in a spruce forest soil to wood ash addition corresponding to 0, 5, 22, and $167 \mathrm{t}$ wood ash ha ${ }^{-1}$. We used culture-based enumerations of general bacteria, Pseudomonas and sporeforming bacteria combined with 16S rRNA gene amplicon sequencing to valuate soil bacterial responses to wood ash application. Results showed that wood ash addition strongly increased soil $\mathrm{pH}$ and electrical conductivity. Soil $\mathrm{pH}$ increased from acidic through neutral at $22 \mathrm{t} \mathrm{ha}^{-1}$ to alkaline at $167 \mathrm{t} \mathrm{ha}^{-1}$. Bacterial numbers significantly increased up to a wood ash dose of $22 \mathrm{t} \mathrm{ha}^{-1}$ followed by significant decrease at $167 \mathrm{t} \mathrm{ha}^{-1}$ wood ash. The soil bacterial community composition changed after wood ash application with copiotrophic bacteria responding positively up to a wood ash dose of $22 \mathrm{t} \mathrm{ha}^{-1}$ while the adverse effect was seen for oligotrophic bacteria. Marked changes in bacterial community composition occurred at a wood ash dose of $167 \mathrm{t} \mathrm{ha}^{-1}$ with a single alkaliphilic genus dominating. Additionally, spore-formers became abundant at an ash dose of $167 \mathrm{tha}^{-1}$ whereas this was not the case at lower 
ash doses. Lastly, bacterial richness and diversity strongly decreased with increasing amount of wood ash applied. All of the observed bacterial responses can be directly explained by the wood ash induced changes in $\mathrm{pH}$, electrical conductivity and the addition of wood ash inherent nutrients.

Keywords: wood ash, renewable energy, forest soil, bacterial community, bacterial numbers, 16S rRNA, CFU, biodiversity

\section{INTRODUCTION}

The increasing use of wood for energy production leads to increased production of wood ash (Karltun et al., 2008; Huotari et al., 2015). Wood ash is often treated as a waste product due to its content of toxic elements (e.g., Cd, As, Cr, and Ni) and a large proportion of the produced wood ash is therefore deposited in landfills (Vance, 1996; Demeyer et al., 2001). This leads to considerable loss of valuable plant nutrients and potential acidification of forest plantation ecosystems (Olsson et al., 1996; Augusto et al., 2008). Wood ash retains most of the major mineral plant nutrients except nitrogen and has liming properties owing to its high content of metal oxides and hydroxides (Demeyer et al., 2001; Augusto et al., 2008). Recirculation of wood ash to forest soils can thus return valuable nutrients to forest ecosystems and counteract soil acidification making energy production by combustion of wood more sustainable.

Wood ash is highly reactive in soil (Karltun et al., 2008) and alters several physio-chemical properties of the soil. Hence, addition of wood ash leads to an increase in soil $\mathrm{pH}$ and pore water electrical conductivity and increased concentrations of elements such as the nutrients $\mathrm{K}, \mathrm{S}, \mathrm{B}, \mathrm{Na}, \mathrm{Ca}, \mathrm{Mg}, \mathrm{Si}, \mathrm{Fe}$, and P (Ohno and Susan Erich, 1990; Demeyer et al., 2001; Pitman, 2006; Augusto et al., 2008). The increase in $\mathrm{pH}$ also changes bioavailability of soil nutrients due to $\mathrm{pH}$-dependent soil chemical equilibria (Khanna et al., 1994; Demeyer et al., 2001). Soil microorganisms are known to respond to these wood ash induced changes (Aronsson and Ekelund, 2004; Huotari et al., 2015). In particular soil pH (Fierer and Jackson, 2006; Lauber et al., 2009; Rousk et al., 2010; Kaiser et al., 2016; Kim et al., 2016) and electrical conductivity (which is correlated to pore water salt concentration) (Lozupone and Knight, 2007; Kim et al., 2016) have been shown to be main drivers in shaping bacterial communities in various soils. Additionally, marked changes to soil systems are known to induce sporulation of soil bacteria as a survival mechanism to unfavorable conditions (Lowe et al., 1989; Nicholson et al., 2000).

Soil bacteria are essential forest soil ecosystem drivers carrying out processes such as decomposition of organic matter, nutrient cycling and greenhouse gas production and play a crucial role as part of the lower trophic levels of the soil food web (Paul, 2014). Changes in bacterial community can thus affect soil functioning and soil quality (Wittebolle et al., 2009; Philippot et al., 2013). Indirect measures of wood ash effects on soil bacteria have detected increases in overall mineralization- (Zimmermann and Frey, 2002; Björk et al., 2010; Saarsalmi et al., 2010, 2012), decomposition- (Weber et al., 1985; Moilanen et al., 2002) and respiration rates (Bååth and Arnebrant, 1994; Fritze et al., 2000;
Perkiömäki and Fritze, 2002; Zimmermann and Frey, 2002; Perkiömäki et al., 2003). Direct bacterial responses to wood ash addition include changes in bacterial numbers measured by colony forming units (CFU) (Bååth and Arnebrant, 1994; Fritze et al., 2000), bacterial growth rates measured by ${ }^{3} \mathrm{H}$-thymidine incorporation (Bååth and Arnebrant, 1994; Fritze et al., 2000; Perkiömäki and Fritze, 2002), bacterial community structures analyzed using PLFAs (Frostegård et al., 1993; Fritze et al., 2000; Liiri et al., 2002; Perkiömäki and Fritze, 2002; Mahmood et al., 2003; Peltoniemi et al., 2016; Cruz-Paredes et al., 2017), 16S rRNA DGGE (Perkiömäki and Fritze, 2003), T-RFLP (Noyce et al., 2016) and amplicon sequencing (Noyce et al., 2016) and bacterial substrate utilization using Biolog plates (Fritze et al., 2000; Merino et al., 2016). The majority of these studies report increased bacterial growth rates and quantities after wood ash addition combined with changes in bacterial community structure and function. These changes are correlated to the applied dose of wood ash and have generally been linked to ash induced $\mathrm{pH}$ increases in soil. Despite of this, reports on bacterial responses to ash addition remain relatively sparse and ambiguous (Aronsson and Ekelund, 2004). Additionally, the vast majority of reported bacterial community responses are the results of methods that only reveal shifts in bacterial community at a general taxonomic level (e.g., PLFA, DGGE, and T-RFLP). More knowledge on bacterial responses at lower taxonomic levels is thus strongly needed to reveal wood ash induced responses in specific bacterial groups which are important for soil ecosystem functioning.

In our study, we aim to investigate bacterial community responses to wood ash addition in a spruce forest soil using $16 \mathrm{~S}$ amplicon sequencing of bacterial rDNA and three CFU approaches. The high-throughput sequencing technique allows an in-depth analysis of bacterial communities. We investigate the application of wood ash in doses within the current legislation $\left(5 \mathrm{t} \mathrm{ha}^{-1}\right)$, four times the currently allowed dose $\left(22 \mathrm{t} \mathrm{ha}^{-1}\right)$ and at an extreme dose of $167 \mathrm{t} \mathrm{ha}^{-1}$. The extreme dose was included to allow us to investigate if high ash doses will tip the system and induce detrimental effects on the soil bacterial community. Furthermore, because we hypothesize that wood ash induced changes in soil $\mathrm{pH}$ will be a main driver in shaping the soil bacterial community the chosen wood ash doses represent an increasing soil $\mathrm{pH}$ from acidic through neutral to alkaline conditions.

We hypothesize that changes in $\mathrm{pH}$ and salinity induced by wood ash application will cause significant changes in the soil bacterial community and that these community changes can be observed gradually over time. We further hypothesize that bacterial numbers (CFUs) initially will be stimulated with 
TABLE 1 | Properties of soil and wood ash.

\begin{tabular}{lcccc}
\hline & WC (\%) & OM (\%) & pH & $\begin{array}{c}\text { Conductivity } \\
\left(\mu \mathbf{S ~ c m}^{-1}\right)\end{array}$ \\
\hline Soil: & $145.3 \pm 0.5$ & $80.5 \pm 0.3$ & $4.33 \pm 0.03$ & $108.2 \pm 12.0$ \\
Wood ash: & $0.60 \pm 0.01$ & $6.50 \pm 0.2$ & 12.9 & 20,400 \\
\hline
\end{tabular}

"WC (\%)" refers to gravimetric water content ( $g$ water $g^{-1}$ dry weight soil). "OM (\%)" refers to organic matter (loss on ignition - g organic matter $g^{-1}$ dry weight soil). " \pm " denote standard error of the mean (SEM) of triplicates. Numbers without " \pm " are measurement on one replicate.

increasing wood ash dose as the $\mathrm{pH}$ of the acidic forest soil will increase until a maximum over which the bacterial abundance decreases due to an alkaline $\mathrm{pH}$ or because other wood ash derived properties become harmful for the majority of soil bacteria. Finally, we also hypothesize that the application of wood ash in high doses will cause unfavorable conditions for most of the indigenous bacteria which are adapted to the non-manipulated soil resulting in a larger frequency of spore forming bacteria.

\section{MATERIALS AND METHODS}

\section{Soil and Wood Ash}

Soil was collected in May 2014 from "Gedhus Plantage" $\left(56^{\circ} 16^{\prime} 38^{\prime \prime} \mathrm{N}, 09^{\circ} 05^{\prime} 12^{\prime \prime} \mathrm{E}\right)$ a 57 -year-old, 2nd generation Norway spruce [Picea abies (L.) Karst.] plantation situated in a relatively undisturbed (i.e., no tilling or addition of fertilizers) previous heathland. The climate is temperate with mean annual precipitation of $850 \mathrm{~mm}$ and mean annual temperature of $8.4^{\circ} \mathrm{C}$. The soil, classified as a podzol, was collected from the O-horizon $(0-10 \mathrm{~cm})$ and homogenized by first removing large roots followed by sieving ( $4 \mathrm{~mm}$ mesh).

The wood ash was a mixture of bottom- and fly ash collected from the local Brande heating plant produced by combustion of wood chips from predominantly coniferous trees. The ash was homogenized by sieving ( $2 \mathrm{~mm}$ mesh).

Properties of the soil and wood ash are presented in Table $\mathbf{1 .}$ Additional elemental composition of the soil and the wood ash can be further inspected in Qin et al. (2017) where the soil and the ash used in the present study were named "Gedhus soil" and "Brande Ash", respectively.

\section{Microcosms}

The homogenized soil and wood ash were separately and repeatedly processed through a riffle splitter to acquire sufficient representative samples. Microcosms were established in triplicates with $150 \mathrm{~g}$ of soil in $11 \mathrm{screw}$ cap glass bottles with wood ash added in doses of $0,5,22$, and $167 \mathrm{t} \mathrm{ha}^{-1}$ (see Supplementary Information 1 for wood ash concentration calculations). The ash doses were chosen based on pilot experiments showing that this range in dosages resulted in $\mathrm{pH}$ responses in the soil ranging from acidic through neutral to alkaline. Additionally, the $5 \mathrm{t} \mathrm{ha}^{-1}$ wood ash dose corresponds approximately to the upper limit of what is currently allowed to add to forest soils in Scandinavian countries (Huotari et al.,
2015) while the doses of 22 and $167 \mathrm{tha}^{-1}$ were included to test for bacterial responses in the soil with doses above the current legislation threshold. Water was added to the microcosms corresponding to $50 \%$ of soil water holding capacity of the soil and ash was mixed well to achieve a homogenous mixture. Microcosms were incubated at $10^{\circ} \mathrm{C}$ under dark and aerobic conditions for 42 days and soil samples were aseptically collected from the microcosms throughout the incubation period to analyze changes in $\mathrm{pH}$, electrical conductivity, and the bacterial community using cultivation-based approaches and 16S rRNA gene amplicon sequencing, as described below.

\section{Electrical Conductivity and pH}

Electrical conductivity and $\mathrm{pH}$ were measured 1, 3, 7, 15, 28, and 42 days after start of incubation. Soil slurries of $5 \mathrm{~g}$ soil to $25 \mathrm{ml}$ Milli-Q water were shaken for $1 \mathrm{~h}$ followed by sedimentation for $2 \mathrm{~h}$. Afterward electrical conductivity was measured in the supernatant using a TetraCon 325 electrode adapted to a conductivity meter Cond 340i (WTW, Weilheim, Germany) followed by measurements of $\mathrm{pH}$ using Sentix 940 electrode connected to a pH meter Multi 9310 (WTW).

\section{Cultivation of Bacteria}

Soil for estimation of numbers of CFU was sampled from the microcosms 3 days after start of incubation. From each microcosm $0.1 \mathrm{~g}$ of soil was collected and used to generate a dilution series in $1 \mathrm{X}$ phosphate buffered saline (PBS) ( $\mathrm{pH} 7.4$ ) ranging from $10^{-1}$ to $10^{-5}$. Subsamples of $50 \mu \mathrm{l}$ of relevant soil dilutions were plated on agar media to quantify (i) general bacteria, (ii) spore forming bacteria and (iii) Pseudomonas.

(i) The growth medium for general bacteria was prepared by combining $7.5 \mathrm{~g} \mathrm{Difco}^{\mathrm{TM}}$ Agar, granulated (Becton, Dickinson and Company, Franklin Lakes, NJ, United States) as the solidifying agent, $0.3 \mathrm{~g}$ Tryptic Soy Broth (TSB) (MoBio, Carlsbad, CA, United States) as the cultivation medium and added Milli-Q water up to a final volume of $500 \mathrm{ml}$. The media was autoclaved at $121^{\circ} \mathrm{C}$ for $20 \mathrm{~min}$ and left to cool to $50^{\circ} \mathrm{C}$ before adding $1 \mathrm{ml}$ anti-fungi agent Delvo-Cid $\left(100 \mathrm{mg} \mathrm{l}^{-1}\right.$ in final solution; DSM Food Specialties, Heerlen, Netherlands).

(ii) The growth medium for the spore forming bacteria was prepared as described above only modified by using $1.5 \mathrm{~g}$ of TSB (MoBio). The soil dilutions used on this medium were pasteurized, i.e., heated to $80^{\circ} \mathrm{C}$ for $10 \mathrm{~min}$ and cooled to room temperature before inoculation on the TSA in order to largely eliminate vegetative bacteria and thus selecting for spore forming bacteria (Vieira and Nahas, 2005).

(iii) The Gould's S1 medium (Gould et al., 1985), selective for Pseudomonas, was prepared by combining $9 \mathrm{~g} \mathrm{Difco}^{\mathrm{TM}}$ Agar (Becton, Dickinson and Company), $5 \mathrm{~g}$ sucrose, $5 \mathrm{ml}$ glycerol, $2.5 \mathrm{~g}$ casamino acids (Becton, Dickinson and Company), $0.5 \mathrm{~g} \mathrm{NaHCO}_{3}, 0.5 \mathrm{~g} \mathrm{MgSO}_{4} \cdot 7 \mathrm{H}_{2} \mathrm{O}, 1.15 \mathrm{~g} \mathrm{~K}_{2} \mathrm{HPO}_{4}, 0.6 \mathrm{~g}$ sodium lauroyl sarcosine $(293.4 \mathrm{M}), 20 \mathrm{mg}$ trimethoprim (Sigma-Aldrich, St. Louis, MO, United States) and added Milli-Q water up to a volume of $500 \mathrm{ml}$.

Dilutions of all samples were inoculated on the different media in five drops of $10 \mu \mathrm{l}$ and were incubated for 7 days at $10^{\circ} \mathrm{C}$. CFUs 
were quantified by visual counts of colonies on a CK40 stereo microscope (Olympus, Japan).

\section{DNA Extraction and Sequencing Library Preparation}

DNA was extracted from $0.25 \mathrm{~g}$ of soil collected from each microcosm 1, 3, 7, 15, 28, and 42 days after start of incubation (in total 72 samples) using PowerLyzer ${ }^{\mathrm{TM}}$ PowerSoil $^{\circledR}$ DNA Isolation Kit (MoBio). A NanoDrop ND-1000 spectrophotometer (Thermo Fischer Scientific Inc., Waltham, MA, United States) was used to measure DNA concentration and to verify DNA purity.

For amplifying the bacterial community from the soil samples the primer pair 515f/806r targeting V4 region of 16S rRNA gene was used [515f: $5^{\prime}$-GTGCCAGCMGCCGCGGTAA-3'; 806r: 5'-GGACTACHVGGGTWTCTAAT-3'; (Caporaso et al., 2012)]. PCR amplifications were performed with primers containing template-specific sequences extended by 2 -nt linker and 4-6-nt barcode (sequence nucleotides of the barcode system are listed in Supplementary Table 1). Each of three independent $10 \mu \mathrm{l}$ reactions per DNA sample contained $2 \mu \mathrm{l} 5 \mathrm{x}$ PCRBIO Reaction Buffer (PCR Biosystems Ltd., London, United Kingdom), $1 \mu \mathrm{l}$ Bovine Serum Albumin (BSA) (Bioron, Ludwigshafen, Germany), $0.2 \mu \mathrm{l} \mathrm{dNTP}(10 \mathrm{mM}), 0.5 \mu \mathrm{L}$ of each primer (10 $\mu \mathrm{M}$ each) with sample specific barcode combinations, $0.1 \mu \mathrm{l}$ PCRBIO HIFI Polymerase (PCR Biosystems Ltd., London,

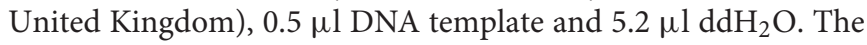
cycling conditions were as follows: $95^{\circ} \mathrm{C}$ for $1 \mathrm{~min}$, followed by 30 cycles at $95^{\circ} \mathrm{C}$ for $15 \mathrm{~s}, 50^{\circ} \mathrm{C}$ for $20 \mathrm{~s}$, then $72^{\circ} \mathrm{C}$ for $20 \mathrm{~s}, 72^{\circ} \mathrm{C}$ for $5 \mathrm{~min}$. The resulting amplicons from technical triplicates were pooled, and amplification was verified by agarose gel electrophoresis. Amplicons were purified using HighPrep ${ }^{\mathrm{TM}}$ PCR clean up system (Magbio Genomics, Gaithersburg, MD, United States), DNA concentration was quantified by Qubit ${ }^{\circledR}$ HS DNA assay (Life Technologies, Darmstadt, Germany) and samples were equimolarly pooled.

Ligation of Illumina adapters was performed using TruSeq DNA PCR-Free LT Sample Prep Kit (Illumina, San Diego, CA, United States). The final amplicon library was subjected to sequencing on Illumina MiSeq $2 \times 250$ bp pair-end platform at the National High-throughput DNA Sequencing Centre (Copenhagen, Denmark).

\section{Bioinformatics}

Sequences (deposited in GenBank, accession numbers SAMN06628931 - SAMN06629002) were processed and analyzed using the following pipeline: Paired-end reads were merged using PEAR (Zhang et al., 2014) with minimum overlap size set to $45 \mathrm{bp}$. Demultiplexing and quality filtering were carried out using QIIME 1.9.1 (Caporaso et al., 2010b) with the following quality filtering settings: Maximum number of consecutive low quality base calls was 5, removal of reads with average Phred quality score below 25, minimum and maximum sequence length was 200 and 320, respectively, maximum number of homopolymers was 6 and sequences that contained ambiguous nucleotides were removed. Chimeras were removed using ChimeraSlayer with the "Gold" reference database (Haas et al., 2011). Operational taxonomic units (OTUs) were picked de novo using UCHIME (Edgar et al., 2011) with $<97 \%$ sequence similarity to separate OTUs. Centroid sequences for each OTU were determined using UCLUST (Edgar, 2010) followed by alignment of sequences using PyNAST (Caporaso et al., 2010a) and taxonomy assignment using UCLUST against the Greengenes database (v. 13_8) (DeSantis et al., 2006). An approximately maximum-likelihood phylogenetic tree was constructed from the centroid sequences using FastTree (Price et al., 2010).

R (v. 3.3.1) (R Core Team, 2017) and the packages vegan (Oksanen et al., 2008) and Phyloseq (McMurdie and Holmes, 2013) were used for further processing, analysis and graphical visualization of the OTU table after removal of singletons, as described in the following.

Metrics of richness (number of observed OTUs) and diversity (Shannon diversity) were calculated based on a rarified number of sequences per sample. Rarefication was done to compensate for variation in read numbers across samples (limit set from the sample with the lowest number of sequences: 10,527 sequences).

The OTU table was normalized using DeSeq2 (Love et al., 2014) prior to calculation of beta-diversity distance matrix using weighted UniFrac metric. The weighted UniFrac dissimilarity matrix was plotted using principal coordinates analysis (PCoA).

\section{Statistical Analysis}

Two-way analysis of variance (ANOVA) was used to test for the effect of ash dose and incubation time on soil $\mathrm{pH}$, electrical conductivity, observed OTUs and Shannon diversity. Because interactions were present in all cases one-way ANOVAs were conducted within each ash dose to test for significant changes in the measurements listed above with incubation time only. One-way ANOVAs were used to test for significant difference in CFUs at the different wood ash doses both within and between the three bacterial groups examined (general bacteria, sporeforming bacteria, and Pseudomonas). The following applies to all the above described ANOVAs: (i) Shapiro-Wilk test was used to test for normal distribution of data. (ii) Levenes test was used to test for equality of variances prior to running ANOVA's and square root data transformation was used when Levenes test showed significant different variances (only true for CFU results). (iii) All ANOVA's were followed by post hoc tests of pair-wise comparisons with Tukey's honest significant difference method.

Linear Pearson correlations were made to test for correlations between wood ash concentrations, soil $\mathrm{pH}$ and soil conductivity. Pearson correlation was also used to test for correlations between wood ash concentration, $\mathrm{pH}$ and soil conductivity to observed OTUs and Shannon diversity.

White's non-parametric $t$-test was used to test for significant differences in relative abundance within the bacterial groups of Alkalibacterium, Paenibacillus, and Pseudomonadaceae. These tests were carried out between day 1 and the remaining incubation times within each of the bacterial groups and within each ash dose. $p$-values were adjusted for false discovery rate using the Benjamini-Hochberg method. The software Statistical 
Analyses of Metagenomic Profiles (STAMP) (Parks and Beiko, 2010) was used to conduct these tests.

Adonis (PERMANOVA) on weighted UniFrac dissimilarity matrix was used to test for significant differences in community composition with the variables ash concentration, $\mathrm{pH}$, electrical conductivity and incubation time. The vegan function Betadisper was used to test for homogeneity of group dispersions.

\section{RESULTS}

\section{pH and Electrical Conductivity}

Wood ash application was positively correlated to soil $\mathrm{pH}$ $(r=0.95, p<0.001)$ and electrical conductivity $(r=0.92$, $p<0.001$ ) (Figure 1). Soil $\mathrm{pH}$ was positively correlated to electrical conductivity $(r=0.98, p<0.001)$. Incubation time had no significant effect on $\mathrm{pH}(p=0.856)$ and electrical conductivity $(p=0.767)$. However, there was a significant $(p=0.003)$ interaction between time and ash concentration on $\mathrm{pH}$ as shown by a significant increase in $\mathrm{pH}$ with time at wood ash doses $5 \mathrm{tha}^{-1}(p=0.016)$ and $22 \mathrm{t} \mathrm{ha}^{-1}(p=0.011)$ whereas time had no effect at wood ash doses 0 and $167 \mathrm{tha}^{-1}$. No significant $(p>0.05)$ interaction between time and ash concentration on soil electrical conductivity was observed.

\section{Culturable Bacteria}

Wood ash addition significantly $(p<0.05)$ affected colony-forming units (CFU) of the three bacterial groups examined 3 days after start of incubation (Figure 2). All changes in $\mathrm{CFU}$ followed the same pattern for all three bacterial groups with significant increases $(p<0.05)$ in CFU from ash dose $0 \mathrm{t}$ $\mathrm{ha}^{-1}$ up to $22 \mathrm{tha}^{-1}$ followed by significant decreases $(p<0.05)$ in CFU from wood ash dose $22 \mathrm{tha}^{-1}-167 \mathrm{t} \mathrm{ha}^{-1}$. CFU counts revealed that there were significant $(p<0.001)$ less spore forming bacteria than general bacteria in the soil at ash dose 0 , 5 , and $22 \mathrm{t} \mathrm{ha}^{-1}$ while no significant $(p>0.05)$ differences were seen at ash dose $167 \mathrm{t} \mathrm{ha}^{-1}$. Ratios of spore forming bacteria to general bacteria in the different ash concentrations are shown in Supplementary Figure 1.

\section{Bacterial Community Sequences}

A total of 2,139,860 reads remained after quality filtering and removal of chimeras and singletons with 10,527 to 48,759 sequences per sample. A total of 69,690 unique OTUs were obtained from these sequences.

\section{Richness and Diversity}

Operational taxonomic unit richness (number of OTUs) and Shannon diversity significantly ( $p<0.001$ for both metrics) decreased with increasing wood ash doses (Figure 3). The interaction between ash dose and time was significant for both metrics (observed OTUs: $p=0.002$; Shannon diversity: $p=0.015)$ and therefore we performed one-way ANOVA followed by Tukey analysis within each ash concentrations to test for significant effects of time on richness and diversity. At $167 \mathrm{t} \mathrm{ha}^{-1}$ ash concentration the number of observed OTUs significantly $(p=0.009)$ decreased with time while Shannon diversity showed a trend $(p=0.082)$ to decrease during incubation. The Tukey test revealed that these decreases were present when comparing incubation times of 1 and 7 days against 42 days. At ash dose $0 \mathrm{t} \mathrm{ha}^{-1}$ the two metrics significantly (observed OTUs: $p=0.042$; Shannon diversity: $p=0.044$ ) increased during incubation. The Tukey test showed that these significances were present only when comparing days 1-42 of incubation. Both metrics did not change significantly $(p>0.05)$ during incubation at wood ash concentration 5 and $22 \mathrm{tha}^{-1}$.

Richness and Shannon diversity were significantly negatively correlated to wood ash concentration, $\mathrm{pH}$ and electrical conductivity (Figure 4). The number of OTUs was strongest negatively correlated to $\mathrm{pH}(r=-0.65)$ followed by a slightly weaker correlation to ash concentration $(r=-0.61)$ and electrical conductivity $(r=-0.48)$. Shannon diversity was strongest negatively correlated to wood ash concentration $(r=-0.51)$ followed by a slightly weaker correlation to $\mathrm{pH}(r=-0.50)$ and a weaker correlation to electrical conductivity $(r=-0.33)$ (Figure 4$)$.

\section{Bacterial Community Composition}

A total of 25 bacterial phyla were found in the soil. The bacterial communities were dominated (average relative abundance $>2 \%$ ) by seven phyla together accounting for $83.7 \% \pm 1.0 \%$ (SEM, $n=72$ ) of the total relative abundance of the bacterial community (Figure 5). The phyla Proteobacteria, Bacteroidetes, and Acidobacteria were the three most dominating phyla in all samples accounting, on average, for $64.1 \pm 3.0 \%$ of the total relative abundance. The most marked changes in relative abundance (\%) were: Acidobacteria decreased from $26.9 \pm 0.5 \%$ at day 1 with no ash addition to $23.5 \pm 0.3 \%$, $17.6 \pm 4.2 \%, 10.1 \pm 2.0 \%$, and $8.2 \pm 5.7 \%$ after 42 days at ash dose $0,5,22$, and $167 \mathrm{t} \mathrm{ha}^{-1}$, respectively. Bacteroidetes increased from $14.2 \pm 0.1 \%$ at day 1 with no ash addition to $17.3 \pm 0.6 \%, 35.6 \pm 5.1 \%$, and $41.4 \pm 0.6 \%$ after 42 days at ash doses 0,5 , and $22 \mathrm{tha}^{-1}$, respectively, and a decrease to $1.9 \pm 0.9 \%$ after 42 days at ash dose $167 \mathrm{t} \mathrm{ha}^{-1}$. Firmicutes increased from $0.1 \pm 0.01 \%$ at day 1 with no ash added to $5.1 \pm 3.5 \%, 15.0 \pm 0.2 \%$, and $56.9 \pm 23.4 \%$ after 42 days at ash doses 5, 22, and $167 \mathrm{t} \mathrm{ha}^{-1}$, respectively. The relative abundance of Proteobacteria decreased from day 1 to day 42 for all investigated ash doses with $30.2 \pm 0.7 \%$ to $19.4 \pm 0.1 \%$, $34.0 \pm 1.3 \%$ to $22.6 \pm 0.7 \%, 37.5 \pm 1.0 \%$ to $25.9 \pm 2.7 \%$ and $32.8 \pm 1.1 \%$ to $12.5 \pm 7.1$ for ash doses $0,5,22$, and $167 \mathrm{tha}^{-1}$, respectively. Supplementary Table 2 shows the relative abundance of the seven most abundant phyla for each dose of ash at days 1 and 42 where the most pronounced differences in the dominant phyla were observed.

Three taxonomic groups at a lower taxonomic level than phylum (genus: Alkalibacterium; genus Paenibacillus; family: Pseudomonadaceae) show interesting responses in relative abundance after wood ash application and are presented in Figure 6. The complete overview of the relative abundance of the whole bacterial community from phyla to genus level is available in Supplementary Data 1.

The added ash doses resulted in significantly $(p<0.001$, $R^{2}=0.276$; Adonis (PERMANOVA) on weighted unifrac 


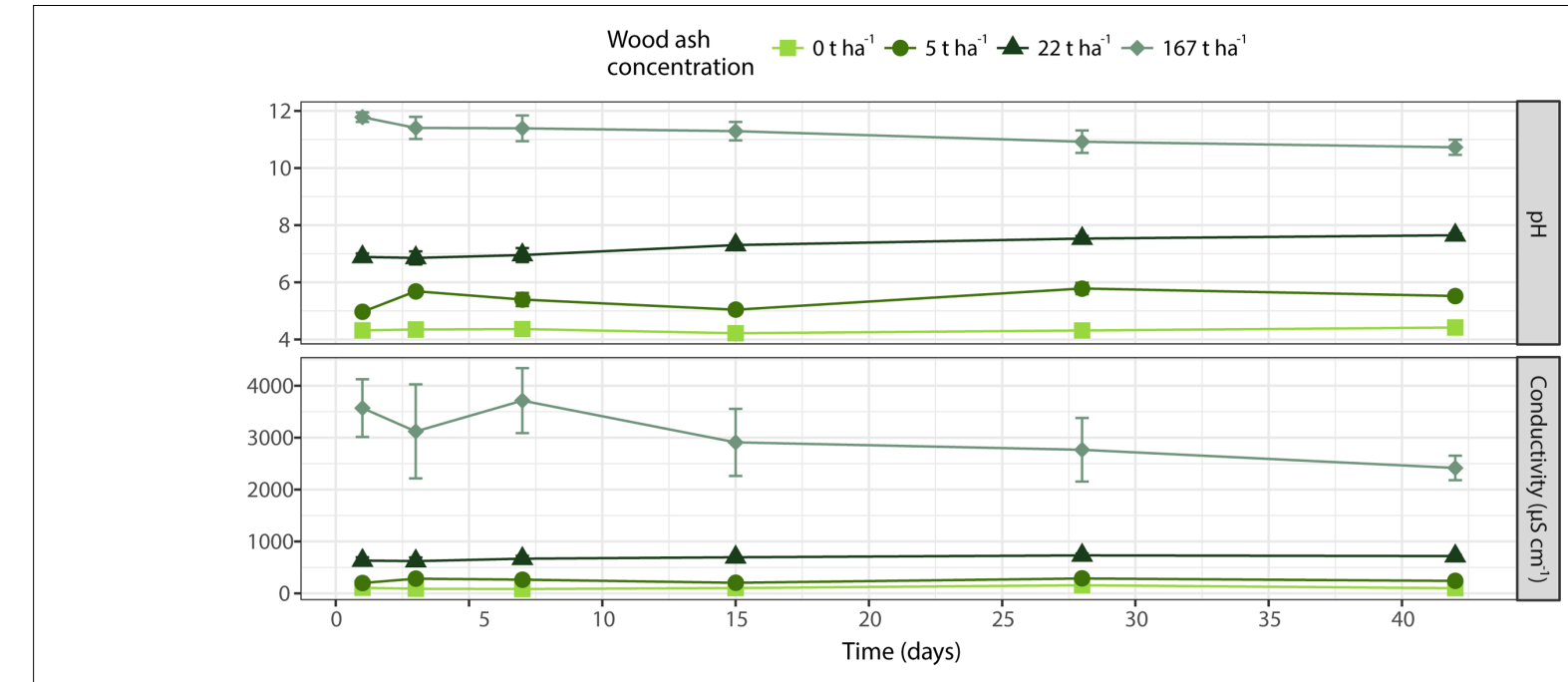

FIGURE 1 | Soil pH (top) and electrical conductivity (bottom) during incubation time. Different wood ash concentrations are represented with different colors and symbols. Each symbol denotes average of triplicates \pm SEM.

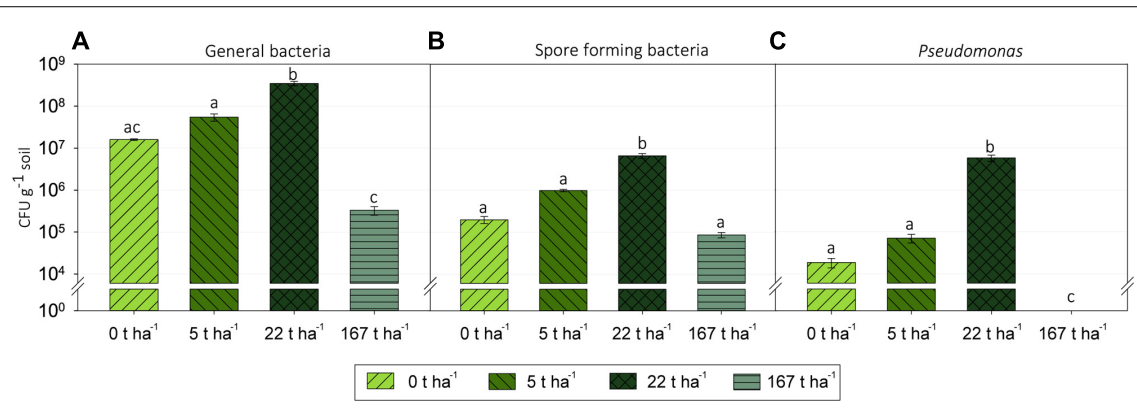

FIGURE 2 | Colony forming units (CFU) per gram of soil in the microcosms of increasing wood ash concentration at day 3 of incubation on agar media selecting for: (A) General bacteria, (B) spore forming bacteria and (C) Pseudomonas spp. Statistically significant effect of wood ash addition on CFU counts $(p<0.05)$ within each media type is indicated by different letters. Bars represent average CFU $\mathrm{g}^{-1}$ soil of three replicates $\pm \mathrm{SEM}$. Detection limit for the general bacteria and the spore forming bacteria was $200 \mathrm{CFU} \mathrm{g}^{-1}$ soil and $400 \mathrm{CFU} \mathrm{g}^{-1}$ soil for the Pseudomonas selective media.

dissimilarity) different bacterial communities (Figure 7). Results from pairwise comparisons between bacterial communities at different ash doses can be seen in Supplementary Table 3. Soil $\mathrm{pH}$, electrical conductivity and incubation time also explained the grouping of the bacterial communities (all $p<0.001$ ) but with lower $R^{2}$ values $(0.243,0.218$, and 0.068 for $\mathrm{pH}$, electrical conductivity and incubation time, respectively) than ash dose.

\section{DISCUSSION}

\section{Effect of Wood Ash addition on Soil pH and Electrical Conductivity}

Soil $\mathrm{pH}$ and electrical conductivity correlated significantly with the ash dosage applied to the spruce forest soil. These observations are consistent with previously reported increases in soil pH (Ohno and Susan Erich, 1990; Clapham and Zibilske, 1992; Kahl et al., 1996; Demeyer et al., 2001) and electrical conductivity (Clapham and Zibilske, 1992; Eriksson et al., 1998;
Arvidsson and Lundkvist, 2003) in various soil types after ash addition. The increases in soil $\mathrm{pH}$ and electrical conductivity were observed 1 day after incubation and remained stable (no significant changes) throughout the incubation period (Figure 1). The soil-ash interaction thus reached its equilibrium shortly after application of ash to the soil. These observations are consistent with other studies showing that loose and fine-particulate wood ash is highly reactive in soils (Clapham and Zibilske, 1992; Ulery et al., 1993; Muse and Mitchell, 1995; Vance, 1996; Karltun et al., 2008). However, $\mathrm{pH}$ continued to increase during the incubation for the applied ash concentrations 5 and $22 \mathrm{tha}^{-1}$ with increases from 5.0 to 5.5 and 6.9 to 7.7 from incubation time day 1 to 48 days, respectively.

\section{Effect of Wood Ash Addition on Culturable Soil Bacteria and Formation of Spores}

Measured as CFU, bacteria were stimulated with application of wood ash for all investigated bacterial groups up to an ash dose of 


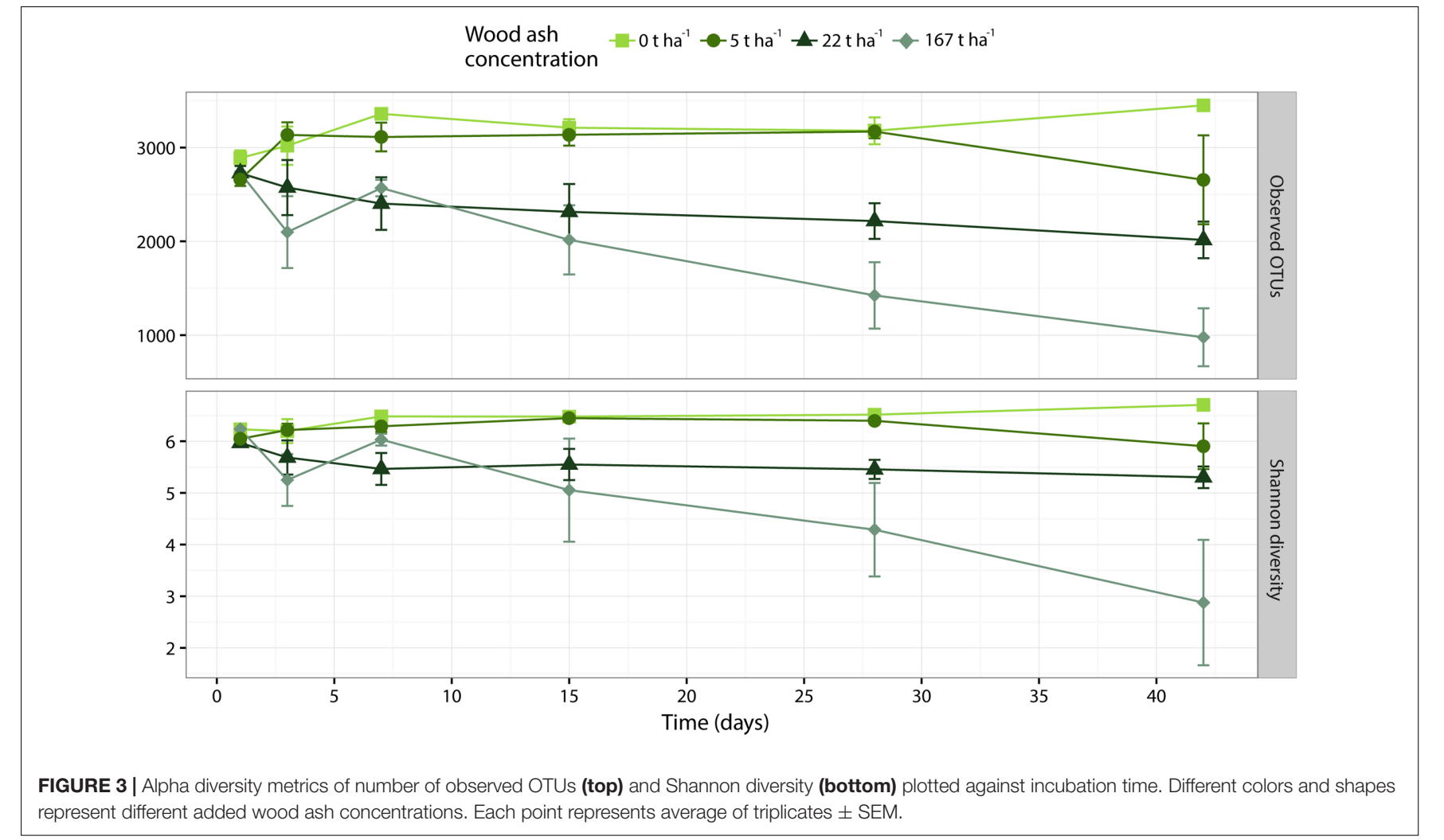

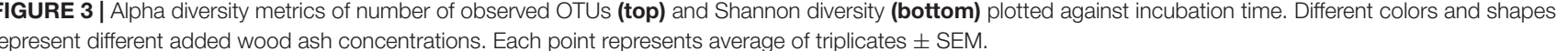

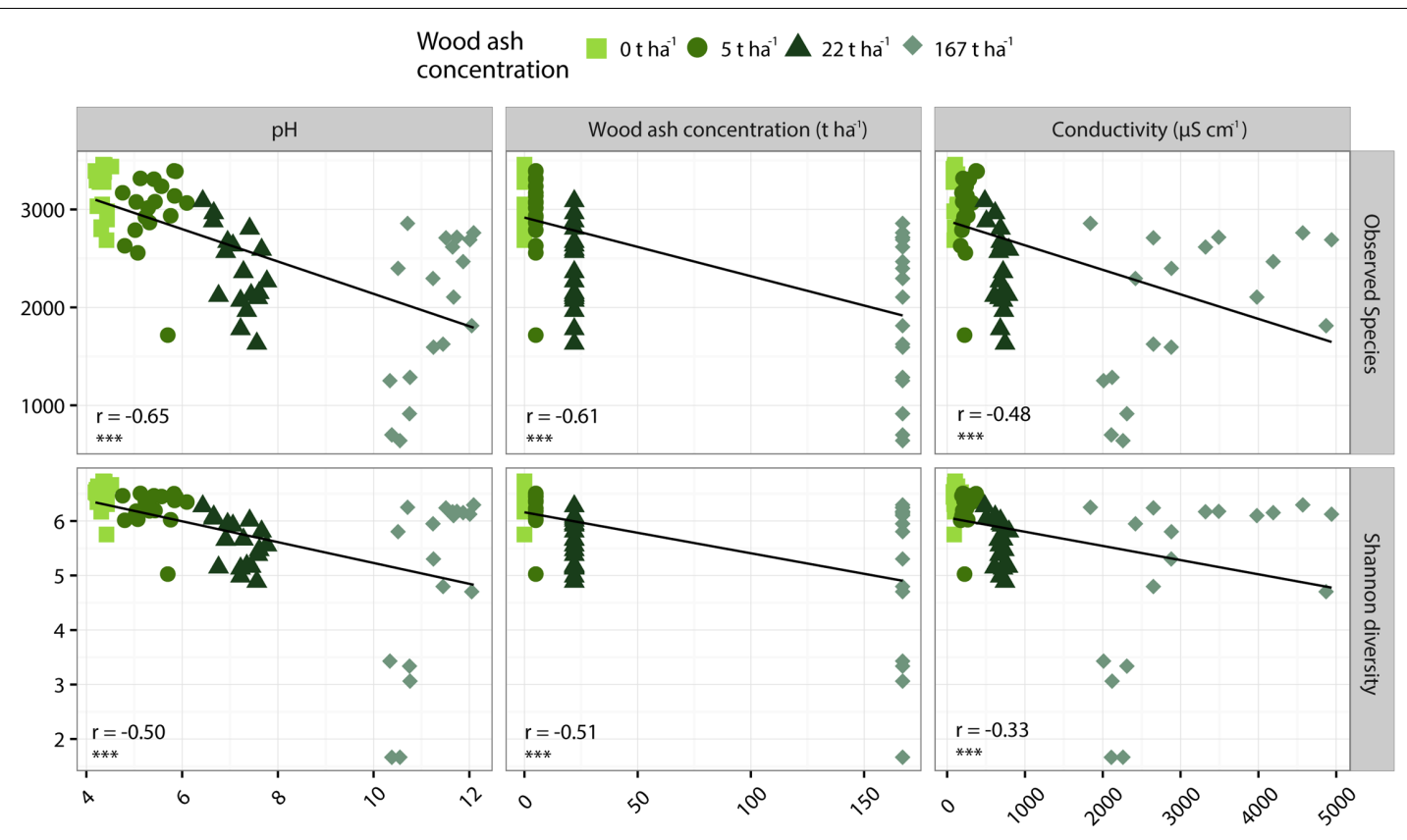

FIGURE 4 | Pearson correlations of number of OTUs (top row) and Shannon diversity (bottom row) to soil pH (left column), wood ash concentration (middle column) and electrical conductivity (right column). $r$ - and $p$-values of each Pearson correlation is given in lower left corner of each plot with $p<0.001$ indicated by ${ }^{* * *}$.

$22 \mathrm{tha}^{-1}$ followed by a significant decrease at $167 \mathrm{tha}^{-1}$ wood ash addition (Figure 2). The increased bacterial numbers after ash application is consistent with previously reported increases in microbial numbers and bacterial growth after ash application (Bååth and Arnebrant, 1994; Fritze et al., 2000; Perkiömäki and Fritze, 2002; Aronsson and Ekelund, 2004). The stimulation of 


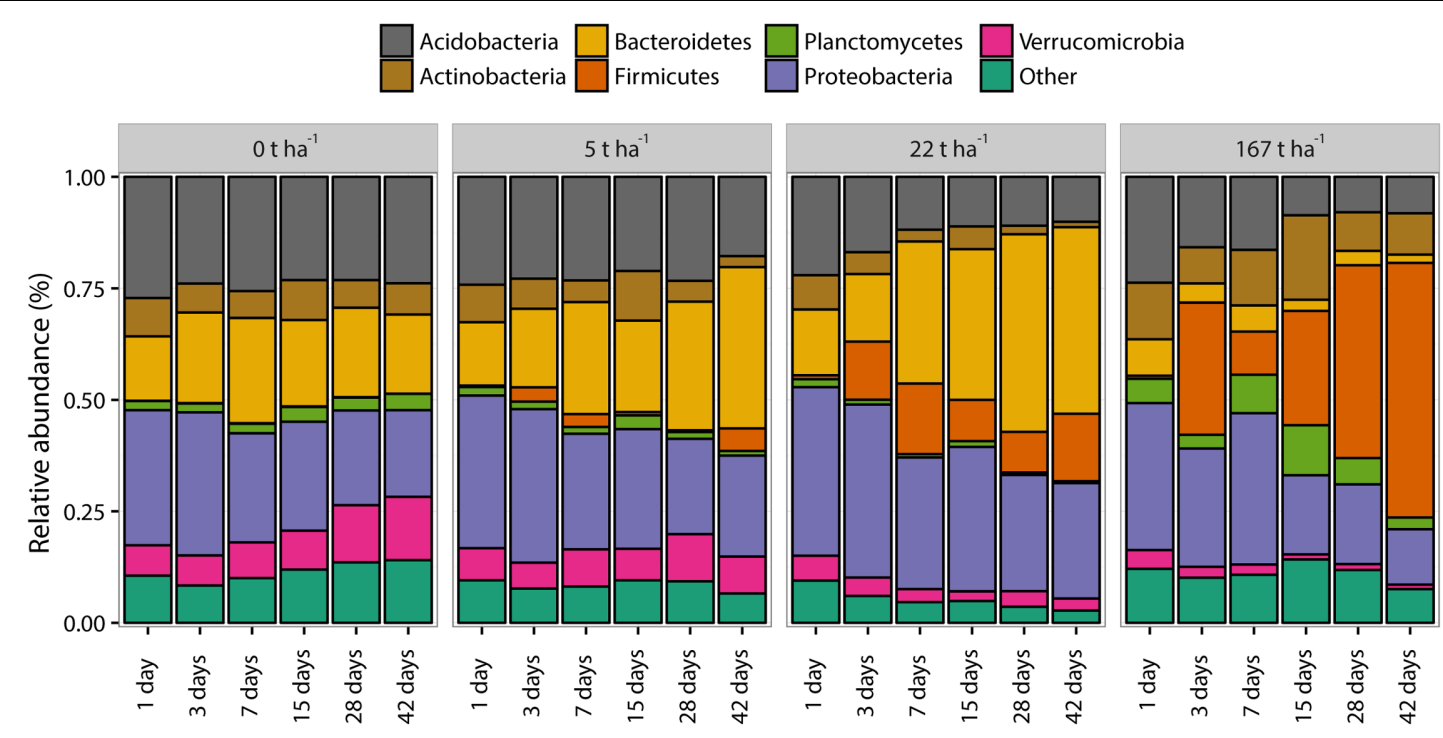

FIGURE 5 | Bacterial community structure at phylum level for increasing wood ash concentrations and increasing incubation time. Presented phyla have an average relative abundance of $\geq 2 \%$. "Other" represents all phyla with $<2 \%$ average relative abundance. Each bar represents the mean of triplicates.

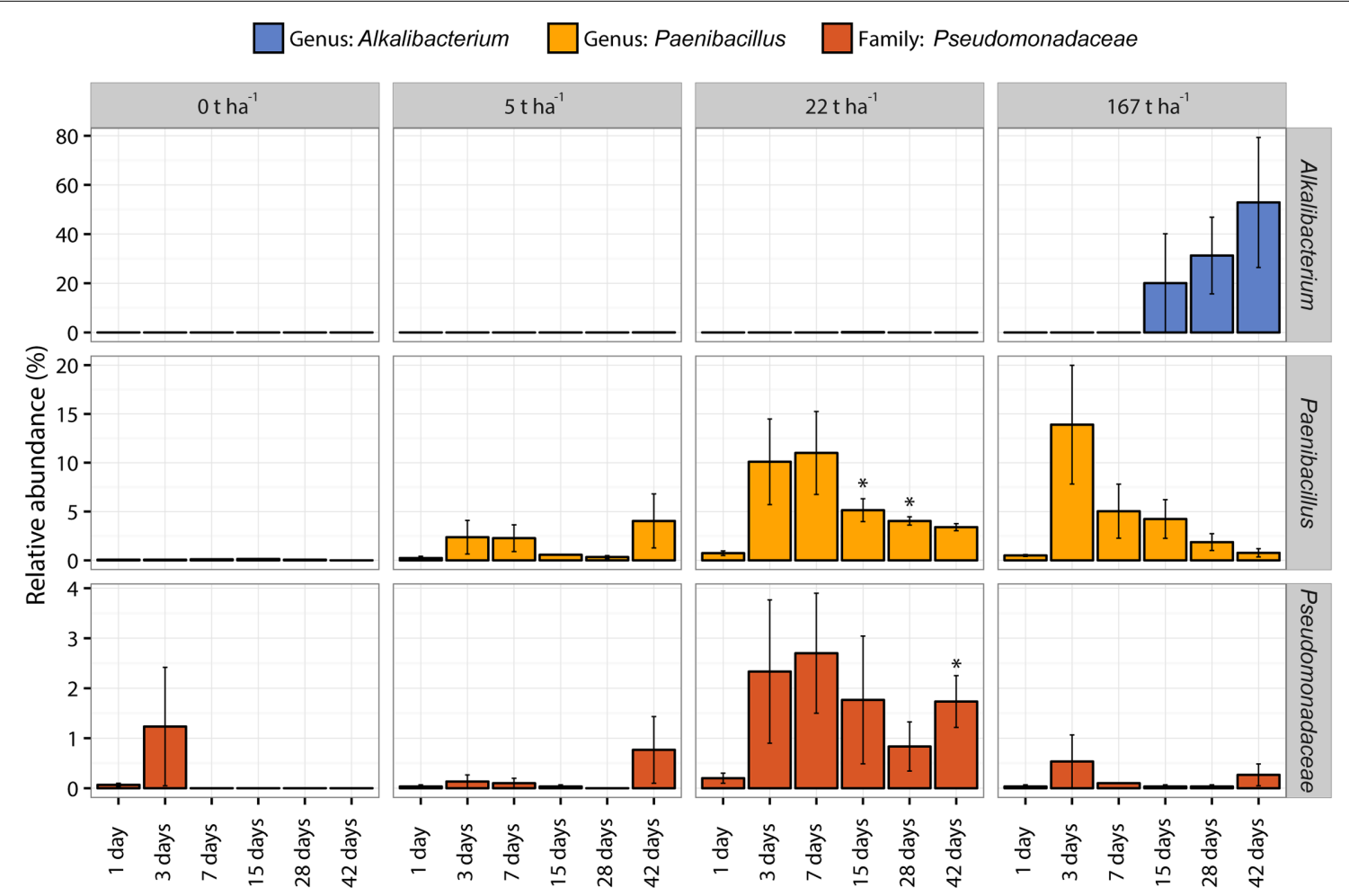

FIGURE 6 | Relative abundance (\%) of the genus Alkalibacterium (blue bars), genus Paenibacillus (yellow bars), and family Pseudomonadaceae (red bars) of increasing wood ash addition (from $0 \mathrm{t} \mathrm{ha}^{-1}$ in left column to $167 \mathrm{t} \mathrm{ha}^{-1}$ in right column) with increasing incubation time on $x$-axis within each plot. Bars represent average of triplicates \pm SEM. Asterisks $\left(^{*}\right)$ indicate significant $(p<0.05)$ difference in relative abundance to day 1 within the same taxonomic group and ash concentration.

bacterial numbers can to a large extent be explained by the increase in soil $\mathrm{pH}$. The soil $\mathrm{pH}$ was raised from acidic $(\mathrm{pH} 4.3)$ at an ash dose of $0 \mathrm{tha}^{-1}$ to around neutral ( $\mathrm{pH}$ 7.2) at an ash dose of $22 \mathrm{tha}^{-1}$ which is comparable to studies observing increased bacterial growth rates and numbers in soil with increasing soil pH (Rousk et al., 2009, 2010; Fernández-Calviño et al., 2011). 


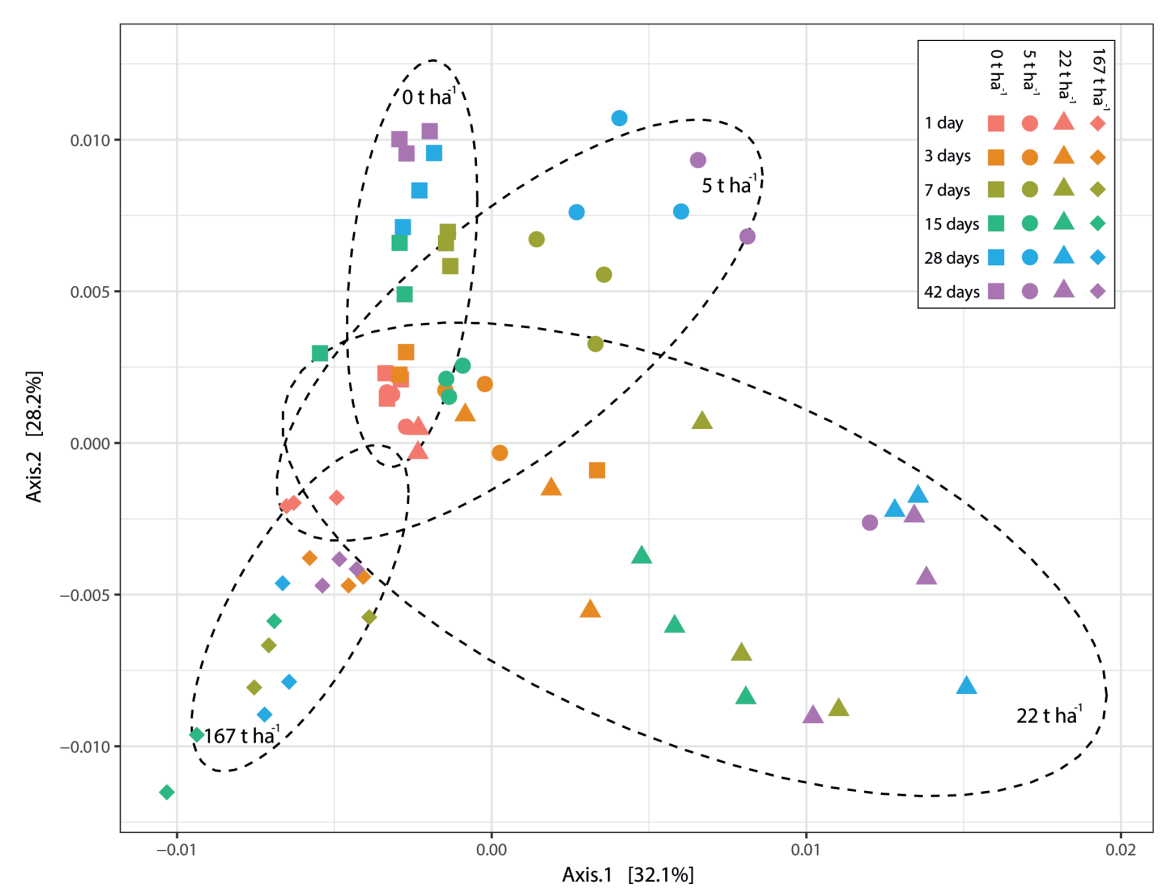

FIGURE 7 | Principal coordinate analysis (PCoA) based on weighted UniFrac dissimilarity. Each point corresponds to a sample. Different colors correspond to different incubation times and different symbols correspond to different wood ash concentrations (as shown in legend). Dashed circles represent $90 \%$ confidence ellipse around samples with same wood ash concentration (concentrations presented inside the different ellipses). The percentage of variation explained by the plotted principal coordinates is indicated on the axes.

The observed increases in bacterial numbers occurred already 3 days after ash application which most likely is the result of fast growing copiotrophs ( $r$-strategist) have favorable conditions in the soil after ash addition. This is supported by the increase in the numbers of Pseudomonas up to ash dose $22 \mathrm{t} \mathrm{ha}^{-1}$ (Figure 2C) because bacteria in the genus Pseudomonas are generally thought to be copiotrophic (Smit et al., 2001; Inceoğlu et al., 2011; Lladó and Baldrian, 2017). Better growth of copiotrophic bacteria after wood ash application is probably due to increased nutrient availability. Nutrients are added directly with the wood ash but easily available nutrients are probably also released from lyzed microorganisms which are killed by the ash induced changes to the soil system. Additionally, the increased soil $\mathrm{pH}$ has an impact on the fraction of bioavailable nutrients in the soil which potentially improve conditions favoring copiotrophic bacteria (Demeyer et al., 2001).

A wood ash dose of $167 \mathrm{t} \mathrm{ha}^{-1}$ resulted in detrimental effects on the soil bacterial numbers with significant decreases. Decreases in bacterial numbers after ash application have, to our knowledge, not been reported before. The $167 \mathrm{tha}^{-1}$ ash dose is, admittedly, an extreme dose causing extreme changes in the soil system. At this ash dose the soil bacteria are exposed to a soil $\mathrm{pH}$ of 11.3 and a 30 -fold increase in electrical conductivity compared to the control soil. These extreme conditions are probably very stressful for many soil bacteria adapted to the conditions of the non-manipulated acidic soil. Other ash inherent components such as the high concentration of ions which change soil water osmolarity and heavy metals are also known to be toxic to microorganisms and are possibly contributing to the detrimental effect seen on bacterial numbers at an ash dosage of $167 \mathrm{tha}^{-1}$.

Numbers of spore forming bacteria were not significantly different from numbers of general bacteria at an ash dose of $167 \mathrm{tha}^{-1}$ (Figures 2A,B). Moreover, the ratio of spore forming bacteria to general bacteria increased markedly from 0.012 to 0.019 at ash doses of $0-22 \mathrm{tha}^{-1}$ up to 0.26 at an ash dose of $167 \mathrm{tha}^{-1}$ (Supplementary Figure 1). A large proportion of the bacteria surviving at a ash concentration of $167 \mathrm{t} \mathrm{ha}^{-1}$ thus go into a dormant spore stage to withstand the extreme conditions (Rothschild and Mancinelli, 2001). For the ash doses of 0, 5, and $22 \mathrm{t} \mathrm{ha}^{-1}$ there were significantly more general bacteria than spore forming bacteria and the ratio of spore forming bacteria to general bacteria was low indicating that bacteria do not need to be in a spore stage to survive the ash induced soil changes here.

\section{Effects of Wood Ash Addition on Soil Bacterial Community}

Richness (observed OTUs) and diversity (Shannon diversity) decreased with increased concentration of wood ash (Figures 3, 4). Richness and diversity showed a clear negative correlation with soil $\mathrm{pH}$, wood ash concentration and electrical conductivity. Of the three variables, $\mathrm{pH}$ had the strongest and electrical conductivity the weakest correlation with richness (Figure 4). With loss of bacterial richness and diversity the overall genepool of the soil is reduced which potentially reduces soil functioning and the stability of the ecosystem (Wittebolle et al., 2009; Philippot et al., 2013). 
However, ANOVA with Tukey post hoc test revealed that the decreases in richness and diversity first became significant after 42 days at $167 \mathrm{t} \mathrm{ha}^{-1}$ wood ash (Figure 3). Wood ash concentrations of 5 and $22 \mathrm{t} \mathrm{ha}^{-1}$ did not result in significant differences in richness or diversity during the experimental period. This demonstrates that it indeed requires extreme ash concentrations to provoke a significant impact on the richness and diversity of the bacterial community in this forest soil. Furthermore, as the bacteria seemed to respond gradually during time after ash application, 42 days were needed to observe a significant effect on bacterial richness and diversity.

Addition of wood ash changed the bacterial community composition and the added wood ash doses was the best explanatory variable for the bacterial community groupings. The higher the ash doses added to the soil the more distantly related bacterial communities observed (Figures 5, 7 and Supplementary Table 3). Additionally, the variables $\mathrm{pH}$, electrical conductivity and incubation time could also significantly explain the observed grouping of the bacterial communities but with weaker explanatory strength than the wood ash concentration [lower $R^{2}$-values using adonis (PERMANOVA)]. Soil $\mathrm{pH}$ and electrical conductivity did only show slightly weaker explanatory strengths than wood ash concentration whereas the explanatory strength of time was much weaker. This indicate that the wood ash induced changes in $\mathrm{pH}$ and electrical conductivity are important determining variables for the observed changes in the bacterial community composition. Moreover, the results indicate that $\mathrm{pH}$ is the more important variable of the two for the observed bacterial community groupings due to a slightly higher explanatory strength of $\mathrm{pH}$ in comparison to electrical conductivity. This is consistent with other studies showing $\mathrm{pH}$ and electrical conductivity (often used as a measure for salinity) to be determining for soil microbial community structure (Fierer and Jackson, 2006; Fierer et al., 2007; Lauber et al., 2009; Rousk et al., 2010; Kim et al., 2016; Ma et al., 2016). An incubation effect on the bacterial communities was present by the gradual change in bacterial communities of soil incubated without wood ash (Figure 7). However, this gradual change over time was also seen in samples with wood ash added and because these samples resulted in significant differences between bacterial communities in comparison to the control soil, the observed bacterial community changes must be regarded mainly as a response to the added wood ash.

The bacterial community composition responses at phylum level (Figure 5 and Supplementary Table 2) show several trends which can be explained by $\mathrm{pH}$ changes and by the ecological classification proposed by Fierer et al. (2007) with copiotrophic (analog to $r$-strategist: fast growing under high nutrient availability, highly variable population size) and oligotrophic (analog to $K$-strategist: slow-growing, more stable population size) bacterial groups, as discussed in the following.

Acidobacteria decreased in relative abundance with wood ash addition. This is similar to previous findings in soil after wood ash application (Noyce et al., 2016). Acidobacteria are predominating in low $\mathrm{pH}$ conditions (Rousk et al., 2010; Kielak et al., 2016) and the increase in soil pH after wood ash addition can explain the observed decrease. Furthermore, Acidobacteria are generally oligotrophic (Smit et al., 2001; Fierer et al., 2007; Inceoğlu et al., 2011; Kielak et al., 2016) and the increased competition with copiotrophic bacteria after the addition of wood ash inherent nutrients might also explain the relative decrease of Acidobacteria.

Bacteroidetes increased in relative abundance up to $22 \mathrm{tha}^{-1}$ wood ash and then decreased with $167 \mathrm{t} \mathrm{ha}^{-1}$ wood ash applied. Increase in Bacteroidetes has previously been reported in soil after wood ash application (Noyce et al., 2016). Bacteroidetes has been shown to be positively correlated with soil $\mathrm{pH}$ (Lauber et al., 2009; Kim et al., 2016). Additionally, Bacteroidetes exhibits copiotrophic lifestyles (Fierer et al., 2007) and has been shown to be some of the initial metabolizers of labile carbon in soil (Padmanabhan et al., 2003). Wood ash application generally increase the concentration of bioavailable nutrients and dissolved organic carbon (DOC) in soil (Demeyer et al., 2001; Augusto et al., 2008). The observed increase in DOC has been explained by increased mineralization rates. Results of Jokinen et al. (2006) illustrated that microbial activity increased with increasing soil $\mathrm{pH}$ (from acidic to neutral) and DOC concentration after wood ash application to soil. The increase in nutrients, the possible increase in easily available carbon and the more neutral $\mathrm{pH}$ at ash dose $22 \mathrm{t} \mathrm{ha}^{-1}$ gives favorable growth conditions for the copiotrophic Bacteroidetes resulting in a larger fraction of the bacterial community being occupied by this group. Bacteroidetes do not seem to be able to cope with the extreme conditions in the soil after the addition of the high ash dose $\left(167 \mathrm{tha}^{-1}\right)$ resulting in a drastic decrease in relative abundance of this phylum. Interestingly, Pseudomonas, another important copiotrophic group followed the same trend as Bacteroidetes (Smit et al., 2001). This is evident in the CFU result (Figure 2C) and in the relative abundance of $16 \mathrm{~S}$ sequencing results of the Pseudomonadaceae (Figure 6) with stimulated numbers and relative abundance up to $22 \mathrm{t} \mathrm{ha}^{-1}$ wood ash addition followed by a decrease at $167 \mathrm{tha}^{-1}$ wood ash addition.

The dominant phylum Proteobacteria decreased in relative abundance from day 1 to day 42 for all applied ash doses but no clear trend was found at lower taxonomic levels inspecting the classes of $\alpha_{-}, \beta-, \gamma-$, and $\delta$-Proteobacteria which otherwise have been shown to respond to $\mathrm{pH}$ changes (Rousk et al., 2010) and to be copiotrophic bacteria (Fierer et al., 2007). Proteobacteria, however, remained at a high relative abundance (12.5-37.4\%) throughout all added ash doses. This might be explained by Proteobacteria in general being rather resistant toward environmental changes (Barnard et al., 2013).

Firmicutes increased in relative abundance with ash addition. This is especially pronounced after 28-42 days at an ash dose of $167 \mathrm{tha}^{-1}$. Firmicutes are known to be able to cope with various environmental stresses (Barnard et al., 2013) and are further known as endospore forming bacteria (de Hoon et al., 2010). Firmicutes are thus capable of surviving and withstanding the extreme conditions introduced by the concentration of $167 \mathrm{tha}^{-1}$ wood ash. This is consistent with the CFU results of the present study showing that total number of culturable bacteria is not significantly different from the number of sporeforming bacteria which are present in the soil after $167 \mathrm{t} \mathrm{ha}^{-1}$ ash application. The increase in Firmicutes can to a large extent be attributed 
to the increase of the genus Alkalibacterium (Figure 6) which dominates the bacterial community after 42 days with $167 \mathrm{t} \mathrm{ha}^{-1}$ ash addition. Alkalibacterium is known to consist of species that are alkaliphilic and halophilic (Ntougias and Russell, 2001; Nakajima et al., 2005; Ishikawa et al., 2009, 2013). This can explain why this genus survives the extreme increases in $\mathrm{pH}$ and salinity (here measured indirectly by electrical conductivity) after the addition of $167 \mathrm{t} \mathrm{ha}^{-1}$ wood ash to soil on the expense of other bacterial taxa.

Species within the genus of Paenibacillus have many known plant growth promoting capabilities such as $\mathrm{N}_{2}$ fixation and suppressing plant pests and pathogens (McSpadden Gardener, 2004; Lal et al., 2016; Rybakova et al., 2016). Responses in a group like Paenibacillus can thus indicate changes to the overall soil quality which is highly relevant in a forest plantation like the one investigated in the present study. The presented DNA data allowed us to see changes in this important genus with ash application where we saw an increase in relative abundance at an ash dose of $22 \mathrm{t} \mathrm{ha}^{-1}$. Species of Paenibacillus have been reported to grow between $\mathrm{pH}$ 5.0-12.0, with an optimum at 7.0-7.2 (von der Weid et al., 2002; Smith et al., 2009; Wang et al., 2013). The $\mathrm{pH}$ optimum around neutral corresponds well with the observed increases in relative abundance of Paenibacillus at an ash dose of $22 \mathrm{tha}^{-1}$ because $\mathrm{pH}$ of the soil is close to the optimum for growth here. The family Pseudomonadaceae likewise contains many species important for plant health and soil quality (Martínez-Viveros et al., 2010; Pereg and McMillan, 2015). Pseudomonadaceae increase in relative abundance at $22 \mathrm{tha}^{-1}$ ash addition which is consistent with CFU counts described above.

Increased incubation time amplified the bacterial community responses (Figures 3, 5, 7). This shows a gradual response of the soil bacteria to the wood ash induced changes in the soil system. In contrast, the culturable bacteria already responded after 3 days of incubation (Figure 2). This may be explained by slow degradation of extracellular DNA in soil (Pietramellara et al., 2009) giving a lag in response of the bacterial community as seen through 16S DNA sequencing. If this is true, there might be a more rapid bacterial response to the ash application which we only see gradually as DNA is degraded in soil. Future studies, examining the short-term microbial responses after wood ash application, could circumvent this potential interfering effect by using transcript-based analysis because of RNA's fast turnover rate in soil.

Our results indicate that wood ash application in concentrations comparable to the upper limits of current legislations in Scandinavian countries $\left(5 \mathrm{t} \mathrm{ha}^{-1}\right)$ increased bacterial numbers and increased the relative abundance of copiotrophic bacterial groups on the expense of oligotrophic groups. A similar response was observed for the application of $22 \mathrm{t} \mathrm{ha}^{-1}$ but with more pronounced effects than at $5 \mathrm{tha}^{-1}$. None of these observed bacterial responses at 5-22 $\mathrm{t} \mathrm{ha}^{-1}$ indicated potential ecosystem damaging effects to the spruce forest plantation investigated here. Detrimental effects on the soil bacteria were, however, observed at a wood ash dose of $167 \mathrm{t} \mathrm{ha}^{-1}$ with a significant decrease in diversity and in numbers of culturable bacteria together with predominance of alkaliphilic, halophilic, and sporeforming bacteria. These detrimental effects are likely to cause unwanted effects on the ecosystem functioning. Already $22 \mathrm{t} \mathrm{ha}^{-1}$ is an unrealistic ash dosage to apply in forestry but the lack of detrimental effect at this high dose provide a safer ground for concluding that the current allowable wood ash dosages are safe. The observed bacterial responses could be explained by the increase in $\mathrm{pH}$, electrical conductivity and nutrients after wood ash application. The initial $\mathrm{pH}$ level of a soil and its buffer capacity and the alkalinity of the applied wood ash is thus determining for potential detrimental effects on soil bacterial communities and thereby ecosystem functioning.

\section{CONCLUSION}

The results of this study show that wood ash application to forest soil can cause significant changes to bacterial numbers, richness, diversity and community composition. The applied ash doses of 5 and $22 \mathrm{t} \mathrm{ha}^{-1}$ increased soil bacterial numbers and resulted in favorable conditions for copiotrophic bacteria and less favorable conditions for oligotrophic bacteria which could be seen directly in a gradually change of the bacterial community composition. Detrimental effects on soil bacteria were only observed in the extreme treatment of $167 \mathrm{t} \mathrm{ha}^{-1}$ with decreasing bacterial numbers and a dramatic change of the bacterial community composition. A single genus, known to thrive under alkaline conditions, dominated the bacterial community aligned with the high ash dose $\left(167 \mathrm{t} \mathrm{ha}^{-1}\right)$ which did make the soil highly alkaline. Spore forming bacteria represent the majority of the bacteria capable of surviving the high ash dose.

\section{AUTHOR CONTRIBUTIONS}

TB-A, JTN, JV, JH, RR, RK, HCBH, and CSJ designed the study. TB-A, JTN, JV, and JH did experimental work and data analysis. TB-A wrote the paper in collaboration with all co-authors.

\section{FUNDING}

This work was supported by the "Center for Bioenergy Recycling (ASHBACK)" project, funded by the Danish Council for Strategic Research (grant no 0603-00587B) and Danish Geocenter (grant no 5298507).

\section{ACKNOWLEDGMENT}

We thank Pia Bach Jakobsen for laboratory guidance.

\section{SUPPLEMENTARY MATERIAL}

The Supplementary Material for this article can be found online at: http://journal.frontiersin.org/article/10.3389/fmicb. 2017.01400/full\#supplementary-material 


\section{REFERENCES}

Aronsson, K. A., and Ekelund, N. G. A. (2004). Biological effects of wood ash application to forest and aquatic ecosystems. J. Environ. Qual. 33, 1595-1605. doi: $10.2134 /$ jeq2004.1595

Arvidsson, H., and Lundkvist, H. (2003). Effects of crushed wood ash on soil chemistry in young Norway spruce stands. For. Ecol. Manag. 176, 121-132. doi: 10.1016/S0378-1127(02)00278-5

Augusto, L., Bakker, M. R., and Meredieu, C. (2008). Wood ash applications to temperate forest ecosystems-potential benefits and drawbacks. Plant Soil 306, 181-198. doi: 10.1007/s11104-008-9570-z

Bååth, E., and Arnebrant, K. (1994). Growth rate and response of bacterial communities to $\mathrm{pH}$ in limed and ash treated forest soils. Soil Biol. Biochem. 26, 995-1001. doi: 10.1016/0038-0717(94)90114-7

Barnard, R. L., Osborne, C. A., and Firestone, M. K. (2013). Responses of soil bacterial and fungal communities to extreme desiccation and rewetting. ISME J. 7, 2229-2241. doi: 10.1038/ismej.2013.104

Björk, R. G., Ernfors, M., Sikström, U., Nilsson, M. B., Andersson, M. X., Rütting, T., et al. (2010). Contrasting effects of wood ash application on microbial community structure, biomass and processes in drained forested peatlands. FEMS Microbiol. Ecol. 73, 550-562. doi: 10.1111/j.1574-6941.2010. 00911.x

Caporaso, J. G., Bittinger, K., Bushman, F. D., DeSantis, T. Z., Andersen, G. L., and Knight, R. (2010a). PyNAST: a flexible tool for aligning sequences to a template alignment. Bioinformatics 26, 266-267. doi: 10.1093/bioinformatics/btp636

Caporaso, J. G., Kuczynski, J., Stombaugh, J., Bittinger, K., Bushman, F. D., Costello, E. K., et al. (2010b). QIIME allows analysis of high-throughput community sequencing data. Nat. Methods 7, 335-336. doi: 10.1038/nmeth. f.303

Caporaso, J. G., Lauber, C. L., Walters, W. A., Berg-Lyons, D., Huntley, J., Fierer, N., et al. (2012). Ultra-high-throughput microbial community analysis on the Illumina HiSeq and MiSeq platforms. ISME J. 6, 1621-1624. doi: 10.1038/ismej. 2012.8

Clapham, W. M., and Zibilske, L. M. (1992). Wood ash as a liming amendment. Commun. Soil Sci. Plant Anal. 23, 1209-1227. doi: 10.1080/00103629209368661

Cruz-Paredes, C., Wallander, H., Kjøller, R., and Rousk, J. (2017). Using community trait-distributions to assign microbial responses to $\mathrm{pH}$ changes and $\mathrm{Cd}$ in forest soils treated with wood ash. Soil Biol. Biochem. 112, 153-164. doi: 10.1016/j. soilbio.2017.05.004

de Hoon, M. J. L., Eichenberger, P., and Vitkup, D. (2010). Hierarchical evolution of the bacterial sporulation network. Curr. Biol. 20, R735-R745. doi: 10.1016/j. cub.2010.06.031

Demeyer, A., Voundi Nkana, J., and Verloo, M. (2001). Characteristics of wood ash and influence on soil properties and nutrient uptake: an overview. Bioresour. Technol. 77, 287-295. doi: 10.1016/S0960-8524(00)00043-2

DeSantis, T. Z., Hugenholtz, P., Larsen, N., Rojas, M., Brodie, E. L., Keller, K., et al. (2006). Greengenes, a chimera-checked 16S rRNA gene database and workbench compatible with ARB. Appl. Environ. Microbiol. 72, 5069-5072. doi: 10.1128/AEM.03006-05

Edgar, R. C. (2010). Search and clustering orders of magnitude faster than BLAST. Bioinformatics 26, 2460-2461. doi: 10.1093/bioinformatics/btq461

Edgar, R. C., Haas, B. J., Clemente, J. C., Quince, C., and Knight, R. (2011). UCHIME improves sensitivity and speed of chimera detection. Bioinformatics 27, 2194-2200. doi: 10.1093/bioinformatics/btr381

Eriksson, H. M., Nilsson, T., and Nordin, A. (1998). Early effects of lime and hardened and non-hardened ashes on $\mathrm{pH}$ and electrical conductivity of the forest floor, an relations to some ash and lime qualities. Scand. J. For. Res. 2, 56-66.

Fernández-Calviño, D., Rousk, J., Brookes, P. C., and Bååth, E. (2011). Bacterial $\mathrm{pH}$-optima for growth track soil $\mathrm{pH}$, but are higher than expected at low pH. Soil Biol. Biochem. 43, 1569-1575. doi: 10.1016/j.soilbio.2011. 04.007

Fierer, N., Bradford, M. A., and Jackson, R. B. (2007). Toward an ecological classification of soil bacteria. Ecology 88, 1354-1364.

Fierer, N., and Jackson, R. B. (2006). The diversity and biogeography of soil bacterial communities. Proc. Natl. Acad. Sci. U.S.A. 103, 626-631. doi: 10.1073/ pnas. 0507535103
Fritze, H., Perkiömäki, J., Saarela, U., Katainen, R., Tikka, P., Yrjälä, K., et al. (2000). Effect of Cd-containing wood ash on the microflora of coniferous forest humus. FEMS Microbiol. Ecol. 32, 43-51. doi: 10.1111/j.1574-6941.2000.tb00697.x

Frostegård, Å, Bååth, E., and Tunlio, A. (1993). Shifts in the structure of soil microbial communities in limed forests as revealed by phospholipid fatty acid analysis. Soil Biol. Biochem. 25, 723-730. doi: 10.1016/0038-0717(93)90113-P

Gould, W. D., Hagedorn, C., Bardinelli, T. R., and Zablotowicz, R. M. (1985). New selective media for enumeration and recovery of fluorescent pseudomonads from various habitats. Appl. Environ. Microbiol. 49, 28-32.

Haas, B. J., Gevers, D., Earl, A. M., Feldgarden, M., Ward, D. V., Giannoukos, G., et al. (2011). Chimeric 16S rRNA sequence formation and detection in Sanger and 454-pyrosequenced PCR amplicons. Genome Res. 21, 494-504. doi: $10.1101 /$ gr.112730.110

Huotari, N., Tillman-Sutela, E., Moilanen, M., and Laiho, R. (2015). Recycling of ash - For the good of the environment? For. Ecol. Manag. 348, 226-240. doi: 10.1016/j.foreco.2015.03.008

Inceoğlu, Ö, Al-Soud, W. A., Salles, J. F., Semenov, A. V., and van Elsas, J. D. (2011). Comparative analysis of bacterial communities in a potato field as determined by pyrosequencing. PLoS ONE 6:e23321. doi: 10.1371/journal.pone.0023321

Ishikawa, M., Tanasupawat, S., Nakajima, K., Kanamori, H., Ishizaki, S., Kodama, K., et al. (2009). Alkalibacterium thalassium sp. nov., Alkalibacterium pelagium sp. nov., Alkalibacterium putridalgicola sp. nov. and Alkalibacterium kapii sp. nov., slightly halophilic and alkaliphilic marine lactic acid bacteria isolated from marine organisms and salted foods collected in Japan and Thailand. Int. J. Syst. Evol. Microbiol. 59, 1215-1226. doi: 10.1099/ijs.0.65602-0

Ishikawa, M., Yamasato, K., Kodama, K., Yasuda, H., Matsuyama, M., OkamotoKainuma, A., et al. (2013). Alkalibacterium gilvum sp. nov., slightly halophilic and alkaliphilic lactic acid bacterium isolated from soft and semi-hard cheeses. Int. J. Syst. Evol. Microbiol. 63, 1471-1478. doi: 10.1099/ijs.0.042556-0

Jokinen, H. K., Kiikkilä, O., and Fritze, H. (2006). Exploring the mechanisms behind elevated microbial activity after wood ash application. Soil Biol. Biochem. 38, 2285-2291. doi: 10.1016/j.soilbio.2006.02.007

Kahl, J. S., Fernandez, I. J., Rustad, L. E., and Peckenham, J. (1996). Threshold application rates of wood ash to an acidic forest soil. J. Environ. Qual. 25, 220. doi: 10.2134/jeq1996.00472425002500020003x

Kaiser, K., Wemheuer, B., Korolkow, V., Wemheuer, F., Nacke, H., Schöning, I., et al. (2016). Driving forces of soil bacterial community structure, diversity, and function in temperate grasslands and forests. Sci. Rep. 6:33696. doi: 10.1038/ srep33696

Karltun, E., Saarsalmi, A., Ingerslev, M., Mandre, M., Andersson, S., Gaitnieks, T., et al. (2008). "Wood ash recycling - possibilities and risks," in Sustainable Use of Forest Biomass for Energy, eds D. Röser, A. Asikainen, K. Raulund-Rasmussen, and I. Stupak (Dordrecht: Springer), 79-108. doi: 10.1007/978-1-40205054-1-4

Khanna, P. K., Raison, R. J., and Falkiner, R. A. (1994). Chemical properties of ash derived from Eucalyptus litter and its effects on forest soils. For. Ecol. Manag. 66, 107-125. doi: 10.1016/0378-1127(94)90151-1

Kielak, A. M., Barreto, C. C., Kowalchuk, G. A., van Veen, J. A., and Kuramae, E. E. (2016). The ecology of acidobacteria: moving beyond genes and genomes. Front. Microbiol. 7:744. doi: 10.3389/fmicb.2016.00744

Kim, J. M., Roh, A.-S., Choi, S.-C., Kim, E.-J., Choi, M.-T., Ahn, B.-K., et al. (2016). Soil pH and electrical conductivity are key edaphic factors shaping bacterial communities of greenhouse soils in Korea. J. Microbiol. 54, 838-845. doi: 10.1007/s12275-016-6526-5

Lal, S., Chiarini, L., and Tabacchioni, S. (2016). "New insights in plant-associated Paenibacillus species: biocontrol and plant growth-promoting activity," in Bacilli and Agrobiotechnology, eds M. T. Islam, M. Rahman, P. Pandey, C. K. Jha, and A. Aeron (Cham: Springer International Publishing), 237-279. doi: 10.1007/978-3-319-44409-3-11

Lauber, C. L., Hamady, M., Knight, R., and Fierer, N. (2009). Pyrosequencing-based assessment of soil $\mathrm{pH}$ as a predictor of soil bacterial community structure at the continental scale. Appl. Environ. Microbiol. 75, 5111-5120. doi: 10.1128/AEM. 00335-09

Liiri, M., Setälä, H., Haimi, J., Pennanen, T., and Fritze, H. (2002). Soil processes are not influenced by the functional complexity of soil decomposer food webs under disturbance. Soil Biol. Biochem. 34, 1009-1020. doi: 10.1016/S00380717(02)00034-2 
Lladó, S., and Baldrian, P. (2017). Community-level physiological profiling analyses show potential to identify the copiotrophic bacteria present in soil environments. PLoS ONE 12:e0171638. doi: 10.1371/journal.pone.0171638

Love, M. I., Huber, W., and Anders, S. (2014). Moderated estimation of fold change and dispersion for RNA-seq data with DESeq2. Genome Biol. 15, 550. doi: 10.1186/s13059-014-0550-8

Lowe, S. E., Pankratz, H. S., and Zeikus, J. G. (1989). Influence of pH extremes on sporulation and ultrastructure of Sarcina ventriculi. J. Bacteriol. 171, 3775-3781.

Lozupone, C. A., and Knight, R. (2007). Global patterns in bacterial diversity. Proc. Natl. Acad. Sci. U.S.A. 104, 11436-11440. doi: 10.1073/pnas.0611525104

Ma, J., Ibekwe, A. M., Yang, C.-H., and Crowley, D. E. (2016). Bacterial diversity and composition in major fresh produce growing soils affected by physiochemical properties and geographic locations. Sci. Total Environ. 56, 199-209. doi: 10.1016/j.scitotenv.2016.04.122

Mahmood, S., Finlay, R. D., Fransson, A.-M., and Wallander, H. (2003). Effects of hardened wood ash on microbial activity, plant growth and nutrient uptake by ectomycorrhizal spruce seedlings. FEMS Microbiol. Ecol. 43, 121-131. doi: 10.1111/j.1574-6941.2003.tb01051.x

Martínez-Viveros, O., Jorquera, M., Crowley, D., Gajardo, G., and Mora, M. (2010). Mechanisms and practical considerations involved in plant growth promotion by rhizobacteria. J. Soil Sci. Plant Nutr. 10, 293-319. doi: 10.4067/S071895162010000100006

McMurdie, P. J., and Holmes, S. (2013). phyloseq: an R package for reproducible interactive analysis and graphics of microbiome census data. PLOS ONE 8:e61217. doi: 10.1371/journal.pone.0061217

McSpadden Gardener, B. B. (2004). Ecology of Bacillus and Paenibacillus spp. in Agricultural Systems. Phytopathology 94, 1252-1258. doi: 10.1094/PHYTO. 2004.94.11.1252

Merino, A., Omil, B., Fonturbel, M. T., Vega, J. A., and Balboa, M. A. (2016). Reclamation of intensively managed soils in temperate regions by addition of wood bottom ash containing charcoal: SOM composition and microbial functional diversity. Appl. Soil Ecol. 100, 195-206. doi: 10.1016/j.apsoil.2015. 11.029

Moilanen, M., Silfverberg, K., and Hokkanen, T. J. (2002). Effects of wood-ash on the tree growth, vegetation and substrate quality of a drained mire: a case study. For. Ecol. Manag. 171, 321-338. doi: 10.1016/S0378-1127(01)00789-7

Muse, J. K., and Mitchell, C. C. (1995). Paper mill boiler ash and lime byproducts as soil liming materials. Agron. J. 87, 432. doi: 10.2134/agronj1995. $00021962008700030008 \mathrm{x}$

Nakajima, K., Hirota, K., Nodasaka, Y., and Yumoto, I. (2005). Alkalibacterium iburiense sp. nov., an obligate alkaliphile that reduces an indigo dye. Int. J. Syst. Evol. Microbiol. 55, 1525-1530. doi: 10.1099/ijs.0.63487-0

Nicholson, W. L., Munakata, N., Horneck, G., Melosh, H. J., and Setlow, P. (2000). Resistance of Bacillus endospores to extreme terrestrial and extraterrestrial environments. Microbiol. Mol. Biol. Rev. 64, 548-572. doi: 10.1128/MMBR.64. 3.548-572.2000

Noyce, G. L., Fulthorpe, R., Gorgolewski, A., Hazlett, P., Tran, H., and Basiliko, N. (2016). Soil microbial responses to wood ash addition and forest fire in managed Ontario forests. Appl. Soil Ecol. 107, 368-380. doi: 10.1016/j.apsoil.2016. 07.006

Ntougias, S., and Russell, N. J. (2001). Alkalibacterium olivoapovliticus gen. nov., sp. nov., a new obligately alkaliphilic bacterium isolated from edible-olive washwaters. Int. J. Syst. Evol. Microbiol. 51, 1161-1170. doi: 10.1099/00207713-51-31161

Ohno, T., and Susan Erich, M. (1990). Effect of wood ash application on soil pH and soil test nutrient levels. Agric. Ecosyst. Environ. 32, 223-239. doi: 10.1016/ 0167-8809(90)90162-7

Oksanen, J., Kindt, R., Legendre, P., O’Hara, B., Simpson, G. L., Solymos, P., et al. (2008). vegan: Community Ecology Package. Available at: https://cran.r-project. org/web/packages/vegan/

Olsson, B. A., Bengtsson, J., and Lundkvist, H. (1996). Effects of different forest harvest intensities on the pools of exchangeable cations in coniferous forest soils. For. Ecol. Manag. 84, 135-147. doi: 10.1016/0378-1127(96)03730-9

Padmanabhan, P., Padmanabhan, S., DeRito, C., Gray, A., Gannon, D., Snape, J. R., et al. (2003). Respiration of 13C-labeled substrates added to soil in the field and subsequent $16 \mathrm{~S}$ rRNA gene analysis of 13C-labeled soil DNA. Appl. Environ. Microbiol. 69, 1614-1622. doi: 10.1128/AEM.69.3.1614-1622.2003
Parks, D. H., and Beiko, R. G. (2010). Identifying biologically relevant differences between metagenomic communities. Bioinformatics 26, 715-721. doi: 10.1093/ bioinformatics/btq041

Paul, E. A. (2014). Soil Microbiology, Ecology and Biochemistry, 4th Edn. Waltham, MA: Academic Press.

Peltoniemi, K., Pyrhönen, M., Laiho, R., Moilanen, M., and Fritze, H. (2016). Microbial communities after wood ash fertilization in a boreal drained peatland forest. Eur. Journal Soil Biol. 76, 95-102. doi: 10.1016/j.ejsobi.2016.08.004

Pereg, L., and McMillan, M. (2015). Scoping the potential uses of beneficial microorganisms for increasing productivity in cotton cropping systems. Soil Biol. Biochem. 80, 349-358. doi: 10.1016/j.soilbio.2014.10.020

Perkiömäki, J., and Fritze, H. (2002). Short and long-term effects of wood ash on the boreal forest humus microbial community. Soil Biol. Biochem. 34, 1343-1353. doi: 10.1016/S0038-0717(02)00079-2

Perkiömäki, J., and Fritze, H. (2003). Does simulated acid rain increase the leaching of cadmium from wood ash to toxic levels to coniferous forest humus microbes? FEMS Microbiol. Ecol. 44, 27-33. doi: 10.1111/j.1574-6941.2003. tb01087.x

Perkiömäki, J., Tom-Petersen, A., Nybroe, O., and Fritze, H. (2003). Boreal forest microbial community after long-term field exposure to acid and metal pollution and its potential remediation by using wood ash. Soil Biol. Biochem. 35, 1517-1526. doi: 10.1016/S0038-0717(03)00250-5

Philippot, L., Spor, A., Hénault, C., Bru, D., Bizouard, F., Jones, C. M., et al. (2013). Loss in microbial diversity affects nitrogen cycling in soil. ISME J. 7, 1609-1619. doi: 10.1038/ismej.2013.34

Pietramellara, G., Ascher, J., Borgogni, F., Ceccherini, M. T., Guerri, G., and Nannipieri, P. (2009). Extracellular DNA in soil and sediment: fate and ecological relevance. Biol. Fertil. Soils 45, 219-235. doi: 10.1007/s00374-0080345-8

Pitman, R. M. (2006). Wood ash use in forestry - a review of the environmental impacts. Forestry 79, 563-588. doi: 10.1093/forestry/cpl041

Price, M. N., Dehal, P. S., and Arkin, A. P. (2010). FastTree 2-approximately maximum-likelihood trees for large alignments. PLoS ONE 5:e9490. doi: 10.1371/journal.pone.0009490

Qin, J., Hovmand, M. F., Ekelund, F., Rønn, R., Christensen, S., Groot, G. A., et al. (2017). Wood ash application increases $\mathrm{pH}$ but does not harm the soil mesofauna. Environ. Pollut. 224, 581-589. doi: 10.1016/j.envpol.2017.02.041

R Core Team (2017). R: A Language and Environment for Statistical Computing. Vienna: R Foundation for Statistical Computing. Available at: https://www.Rproject.org/

Rothschild, L. J., and Mancinelli, R. L. (2001). Life in extreme environments. Nature 409, 1092-1101. doi: 10.1038/35059215

Rousk, J., Bååth, E., Brookes, P. C., Lauber, C. L., Lozupone, C., Caporaso, J. G., et al. (2010). Soil bacterial and fungal communities across a $\mathrm{pH}$ gradient in an arable soil. ISME J. 4, 1340-1351. doi: 10.1038/ismej.2010.58

Rousk, J., Brookes, P. C., and Bååth, E. (2009). Contrasting soil pH effects on fungal and bacterial growth suggest functional redundancy in carbon mineralization. Appl. Environ. Microbiol. 75, 1589-1596. doi: 10.1128/AEM. 02775-08

Rybakova, D., Cernava, T., Köberl, M., Liebminger, S., Etemadi, M., and Berg, G. (2016). Endophytes-assisted biocontrol: novel insights in ecology and the mode of action of Paenibacillus. Plant Soil 405, 125-140. doi: 10.1007/s11104-0152526-1

Saarsalmi, A., Smolander, A., Kukkola, M., and Arola, M. (2010). Effect of wood ash and nitrogen fertilization on soil chemical properties, soil microbial processes, and stand growth in two coniferous stands in Finland. Plant Soil 331, 329-340. doi: 10.1007/s11104-009-0256-y

Saarsalmi, A., Smolander, A., Kukkola, M., Moilanen, M., and Saramäki, J. (2012). 30-Year effects of wood ash and nitrogen fertilization on soil chemical properties, soil microbial processes and stand growth in a Scots pine stand. For. Ecol. Manag. 278, 63-70. doi: 10.1016/j.foreco.2012.05.006

Smit, E., Leeflang, P., Gommans, S., van den Broek, J., van Mil, S., and Wernars, K. (2001). Diversity and seasonal fluctuations of the dominant members of the bacterial soil community in a wheat field as determined by cultivation and molecular methods. Appl. Environ. Microbiol. 67, 2284-2291. doi: 10.1128/ AEM.67.5.2284-2291.2001

Smith, S. A., Benardini, J. N., Strap, J. L., and Crawford, R. L. (2009). Diversity of aerobic and facultative alkalitolerant and halotolerant endospore formers 
in soil from the Alvord Basin, Oregon. Syst. Appl. Microbiol. 32, 233-244. doi: 10.1016/j.syapm.2008.09.008

Ulery, A. L., Graham, R. C., and Amrhein, C. (1993). Wood-ash composition and soil ph following intense burning. Soil Sci. 156, 358-364. doi: 10.1097/ 00010694-199311000-00008

Vance, E. D. (1996). Land application of wood-fired and combination boiler ashes: an overview. J. Environ. Qual. 25, 937. doi: 10.2134/jeq1996. 00472425002500050002x

Vieira, F. C. S., and Nahas, E. (2005). Comparison of microbial numbers in soils by using various culture media and temperatures. Microbiol. Res. 160, 197-202. doi: 10.1016/j.micres.2005.01.004

von der Weid, I., Duarte, G. F., van Elsas, J. D., and Seldin, L. (2002). Paenibacillus brasilensis sp. nov., a novel nitrogen-fixing species isolated from the maize rhizosphere in Brazil. Int. J. Syst. Evol. Microbiol. 52, 2147-2153. doi: 10.1099/ 00207713-52-6-2147

Wang, L.-Y., Li, J., Li, Q. X., and Chen, S.-F. (2013). Paenibacillus beijingensis sp. nov., a nitrogen-fixing species isolated from wheat rhizosphere soil. Antonie Van Leeuwenhoek 104, 675-683. doi: 10.1007/s10482-013-9974-5

Weber, A., Karsisto, M., Leppänen, R., Sundman, V., and Skujiņš, J. (1985). Microbial activities in a histosol: effects of wood ash and NPK fertilizers. Soil Biol. Biochem. 17, 291-296. doi: 10.1016/0038-0717(85)90063-X
Wittebolle, L., Marzorati, M., Clement, L., Balloi, A., Daffonchio, D., Heylen, K., et al. (2009). Initial community evenness favours functionality under selective stress. Nature 458, 623-626. doi: 10.1038/nature07840

Zhang, J., Kobert, K., Flouri, T., and Stamatakis, A. (2014). PEAR: a fast and accurate Illumina Paired-End reAd mergeR. Bioinformatics 30, 614-620. doi: 10.1093/bioinformatics/btt593

Zimmermann, S., and Frey, B. (2002). Soil respiration and microbial properties in an acid forest soil: effects of wood ash. Soil Biol. Biochem. 34, 1727-1737. doi: 10.1016/S0038-0717(02)00160-8

Conflict of Interest Statement: The authors declare that the research was conducted in the absence of any commercial or financial relationships that could be construed as a potential conflict of interest.

Copyright (c) 2017 Bang-Andreasen, Nielsen, Voriskova, Heise, Rønn, Kjøller, Hansen and Jacobsen. This is an open-access article distributed under the terms of the Creative Commons Attribution License (CC BY). The use, distribution or reproduction in other forums is permitted, provided the original author(s) or licensor are credited and that the original publication in this journal is cited, in accordance with accepted academic practice. No use, distribution or reproduction is permitted which does not comply with these terms. 